SYSTEMS ANALYSIS

\section{Going International}

AN International Institute of Applied Systems Analysis is to be established near Vienna to study the problems of modern civilization. The brainchild of President Lyndon Johnson, the institute is the result of five years work by an international committee under Lord Zuckerman, and has been founded by twelve scientific institutions including the Royal Society, the National Academy of Science and the Soviet Academy of Sciences. It is expected to start work next year at the Palace of Laxenburg near Vienna with a budget to start with of $\$ 3.5$ million a year, $\$ 1$ million each being provided by the United States and the Soviet Union and the balance by national governments through the other ten national institutions. Britain's contribution will amount to $\$ 150,000$. The institute is to be non-governmental and will carry out research in new methods of systems analysis, operational research, management techniques and cybernetics with a view to applying them to the problems that confront society.

Speaking at the first plenary meeting of the institute last week, $\mathrm{Mr}$ Michael Noble, Minister of State for Trade and Industry, said that "the age of the computer model is now with us and, from the heated debates about such models, as applied recently to the environment, it is evident that the institute is being born at an auspicious moment when there is as evident a need for a great deal of sound scientific research in the methodology and application of systems analysis".

The first chairman of the council's institute is to be Dr Jermen Gvishiani of the Soviet Academy of Sciences and Dr Howard Raiffa of Harvard University is to be the first director. A permanent staff of between 50 and 100 is to be stationed in Austria, and Sir Kingsley Dunham, chairman of the eighteen-man British National Committee which has been appointed to advise the Royal Society on the conduct of its relations with the institute, said this week that it is hoped that the best brains in the world will be drawn to the institute as visiting consultants.

The institute is to consider projects falling within four chief categories environmental systems, health and care systems, municipal services systems and large engineering design systems. Although details of the first projects will not be available for two or three months, the Americans are believed to favour an early study of energy resources and demands, coupled with a study of likely new sources and technologies.

Hard-hitting reports on subjects as fundamental to government as those the institute intends to cover could well be highly sensitive politically, but it is not yet clear how free from political pressure the institute will be. Sir Kingsley said this week that there is no provision in the institute's charter for restrictions on publication, and certainly all the scientists involved hope that publication will be unrestricted, but he added that details of the institute's freedom to publish have not yet been worked out.

The twelve founder institutions of the IIASA are the Soviet Academy of Sciences, the Committee for the International Institute of Applied Systems Analysis (Canada), the Committee for the IIASA of Czechoslovakia, the French Association for the Development of Systems Analysis, the German Academy of Sciences (GDR), the Japan Committee for the IIASA, the Max Planck Society for the Advancement of Sciences (West Germany), the National Centre for Cybernetics and Computer Techniques (Bulgaria), the US National Academy of Science, the National Research Council of Italy, the Polish Academy of Sciences and the Royal Society of London.

\section{RESEARCH COUNCILS ifil ignots}

LONDON may eventually be warned of impending floods by means of an early warning station off the coast of Scotland. The Institute of Coastal Oceanography and Tides has identified a site between 20 and 40 miles east of Aberdeen as the best location for trials of a prototype data buoy which will shortly be available for testing. The objective is to measure offshore sea levels in order to provide early warnings of storm surges in the North Sea. The proposed station, which will not be a practicable proposition for some years yet, should help establish a surge forecasting system for the southern North Sea and Thames estuary.

The details of the scheme are reported in the Natural Environment Research Council's annual report, published last week (HMSO, £1.20). The report also reveals that the long-term downward trend in levels of zooplankton in the North Sea and North Atlantic have continued. Plankton numbers have been recorded since 1948, and the 1970 figures show a general decline in phytoplankton numbers, although in the English Channel and the northern part of the Irish Sea stocks have remained constant.

Dr R. S. Glover, director of the Institute for Marine Environmental Research which is responsible for monitoring plankton, states that the decline has been attributed to pollution but adds that there is no evidence for this assertion. To remedy the situation, the institute plans to record both physical and chemical factors that are known to affect animals and plants as well as the plankton population.

NERC is also running studies on the site of Maplin airport to discover the effects of London's third airport on wildlife when it opens in 1981. The report says that the site is one of "international scientific importance" and adds that "there will be a need to protect alternative sites for wildlife conservation" as the airport will severely affect the marshes and mudflats near Foulness.

The report lists the council's work in some detail, and provides details of its expenditure, but the council's comments on the current reorganization of government research and development are now of interest to historians only. The report went to press before the white paper was published in July, and whereas the council's evidence to the Select Committee on Science and Technology is included, its comments are restricted to Lord Rothschild's proposals rather than to Lord Jellicoe's decisions. The report does state that "we believe that there should be a closer partnership between the executive departments ... and the research councils than there has been", and concedes that "in the future an increasing task will be to carry out applied research commissioned by the executive departments". But the council's only comment on the white paper as such is a pious hope that it will have created an environment in which the council can continue its work and "complement the work of the executive departments in a spirit of mutual trust and acknowledgment by them and us of our respective functions....".

In the course of the year, the Insect Pathology Unit became a component part of the council with the title Unit of Invertebrate Virology, and the Institute of Marine Biochernistry also joined the council. NERC's expenditure rose from $£ 13.9$ million in 1970 to $£ 16.4$ million in 1971, and the council's need for computing facilities, discussed at length in last year's report, has been met by the Science Research Council, which has provided facilities at its Atlas and Rutherford laboratories. The Institute of Geological Sciences and the Nature Conservancy remained the biggest spenders among the council's thirteen establishments, accounting for $£ 4.0$ million and $£ 2.2$ million respectively. The council also financed 679 research studentships in 1971-72 compared with 633 in the previous year. Provisional figures for this year are 732. Expenditure on research grants rose from $£ 0.97$ million in $1970-71$ to $f 1.1$ million.

\section{SOUTH AFRICA University Agriculture}

from a Correspondent

THE incorporation of South African departments of agriculture into the 